\title{
Effect of Potassium and Molybdenum Fertilization on Sugar Beet Grown in Calcareous Soil
}

\author{
Mahmoud I. I. 1
}

\begin{abstract}
The study aimed to investigate the economic rate of potassium and molybdenum application for sugar beet (Beta vulgaris L.) in the Egyptian calcareous soil. The field experiment was conducted as complete randomized design using 36 plots each is one $\mathrm{m}^{2}$. Potassium showed a significant effect on the growth of sugar beet plant where increased the yield of the whole plant, root, shoot and sugar yield. Amino nitrogen was affected significantly by potassium fertilization, while the dry matter yield and sucrose percentage did show significant effect. The economical addition of potassium was $100 \mathrm{mg} \mathrm{K} / \mathrm{kg}$ soil which increased the sugar yield by $24 \%$ and $35 \%$ for the first and second seasons, respectively. Addition of molybdenum as a micro-nutrient showed that the rate of $0.2 \mathrm{mg} / \mathrm{kg}$ soil was enough to cause the required effect where, the tubers yield were increased by $27 \%$ and consequently the sugar yield increased by $23 \%$. There were no interaction between potassium and molybdenum in their effect on sugar beet growth and yield.
\end{abstract}

\section{INTRODUCTION}

In recent years, there has been rapid development in sugar beet cultivation in the new reclaimed soils in North Coastal Region and of North Tahrir Region (Nubaria) of Arab Republic of Egypt to minimize the gap between the production and consumption of sugar. The soils of this region are mostly calcareous soils. The optimum nutrition in sugar beet production differs in it's response to the different levels of NPK applications. Many search studies had been carried out to reach the optimum addition of the macro-nutrients ( $\mathrm{N}, \mathrm{P}$ and $\mathrm{K}$ ) and the combination between them especially in Soviet Union and Germany.

Mazepin and Udovidchenko (1980) reported that application of $180 \mathrm{~kg} \mathrm{~N}+240 \mathrm{~kg} \mathrm{P}_{2} \mathrm{O}_{5}+180 \mathrm{~kg}$ $\mathrm{K}_{2} \mathrm{O} /$ ha. gave the highest average yield of 38.2 tons roots/ha, 8.4 percent sugar and 93700 roots/ha. Savchenko (1980) in Ukrania showed that application of $60 \mathrm{~kg} \mathrm{~N}+60 \mathrm{~kg} \mathrm{P}_{2} \mathrm{O}_{5}+60 \mathrm{~kg} \mathrm{~K}_{2} \mathrm{O}$, or $120 \mathrm{~kg} \mathrm{~N}+$ $120 \mathrm{~kg} \mathrm{P}_{2} \mathrm{O}_{5}+120 \mathrm{~kg} \mathrm{~K} \mathrm{~K}_{2} \mathrm{O} / \mathrm{ha}$. gave average root yield of 34.8 and 42.6 tons/ha respectively. Tonkal el al., (1980) carried out a trial using 2 sugar beet varieties with no fertilizer or combinations of $90-180 \mathrm{~kg} \mathrm{~N}$, 90-
$136 \mathrm{~kg} \mathrm{P}_{2} \mathrm{O}_{5}$ and 90-360 $\mathrm{kg} \mathrm{K} \mathrm{K}_{2} \mathrm{O} / \mathrm{ha}$. The two varieties differed in their response to the NPK fertilizer. Further increases in NPK rates increased root yield but decreased sugar content, which resulted in lower sugar yield. Orlovius (1986) found that application of mineral $\mathrm{K}$ fertilizer; $450 \mathrm{~kg} \mathrm{~K} \mathrm{~K}_{2} \mathrm{O} /$ ha increased yields by $5 \%$ regardless of residue supply. Cumakov (1996) found that $\mathrm{K}$ had a positive effect on sugar beet and sugar yields. Bieniaszewski (1996) found that application of $\mathrm{N}$ $\mathrm{P} \mathrm{K}$ rates of $60 \mathrm{~kg} \mathrm{~N}+48 \mathrm{~kg} \mathrm{P}_{2} \mathrm{O}_{5}+72 \mathrm{~kg} \mathrm{~K}_{2} \mathrm{O} /$ ha and $1,2,3,4$ or 5 times increased root fresh weights. The optimum dose was $120 \mathrm{~kg} \mathrm{~N}+96 \mathrm{~kg} \mathrm{P}_{2} \mathrm{O}_{5}+144 \mathrm{~kg} \mathrm{~K} 2 \mathrm{O}$ / ha. These rates gave the highest fresh weight being 51.8 ton/ha as compared with no NPK of $41.61 /$ ha. The micro-nutrients such as boron, manganese, iron, cupper and zinc are very important to have healthy plants and consequently, by high root yield and sugar content. Brandenburg (1931), Draycott and Farley (1973), Nagarajah and Ulrich (1966), Rutskaya et al., (1982) and Chielewska et al., (1991) demonstrated the need to add Boron, Manganese, Iron and Zinc to avoid the deficiency symptoms of sugar beet and to get a good quality yield.

The sugar beet demand of micro-nutrients need more studies. Molybdenum is one of these elements which has to be in focus to get healthy plants under the Egyptian soil conditions.

Potassium as essential nutrient is very important to those plants produce tuber root especially in soils poor in potassium. The study conducted aimed the best rate of potassium application and how much need of molybdenum for sugar beet in the Egyptian calcareous soil.

\section{MATERIALS AND METHODS}

Monogerm sugar beet (Beta vulgaris L.) (Plino. Var) seeds were cultivated in calcareous soil using 36 plots each is one $\mathrm{m}^{2}$ and the experiment was conducted as complete randomized design using three replicates. The used soil was chemically analyzed for $\mathrm{pH}$, EC, soluble cations and anions in the soil paste (Table 1) according to standard methods edited by Black (1965).

\footnotetext{
${ }^{1}$ Soil Salinity Dept., Soil, Water and Environment Res. Inst., Agric. Res. Center, Giza, Egypt

Alexandria July 24, 2007, Accepted September 17, 2007
} 
The soil was treated with four levels of potassium added after planting as potassium sulfate at rates of 75,100 , 125 and $150 \mathrm{mg} \mathrm{K}$ per $\mathrm{kg}$ of soil. Foliar addition of molybdenum as ammonium molybdate were done at rates of $0,0.2$ and $0.4 \mathrm{mg} \mathrm{Mo} / \mathrm{kg}$ soil. Superphosphate was added at a rate of $100 \mathrm{mg}$ per $\mathrm{kg}$ of soil. Nitrogen was added in the form of ammonium nitrate at a rate of $100 \mathrm{mg} \mathrm{N}$ per $\mathrm{kg}$ of soil.

Table 1. Chemical properties of the used soil.

\begin{tabular}{|c|c|c|c|c|c|c|c|}
\hline \multirow{2}{*}{$\begin{array}{c}\mathbf{E C} \mathbf{p H} \\
\mathrm{dS} \mathrm{m}^{-1}\end{array}$} & \multicolumn{3}{|c|}{ Cations (meq/L) } & \multicolumn{4}{|c|}{ Anions (meq/L) } \\
\hline & $\mathrm{Ca}^{2+} \mathrm{Mg}^{2+}$ & $\mathrm{Na}^{+}$ & $\mathrm{K}^{+}$ & $\mathrm{HCO}_{3}^{-}$ & $\mathrm{CO}_{3}{ }^{2-}$ & $\mathrm{Cl}^{-}$ & $\mathrm{SO}_{4}{ }^{2-}$ \\
\hline $3.7 \quad 8.0$ & $\begin{array}{ll}10.5 & 6.9 \\
\end{array}$ & 17.2 & 2.2 & 2.5 & n.d. & 31.6 & $\begin{array}{l}5 \quad 3.6 \\
\end{array}$ \\
\hline
\end{tabular}

Nitrogen was added in the form of ammonium nitrate at a rate of $100 \mathrm{mg} \mathrm{N}$ per $\mathrm{kg}$ of soil. Half of this amount was added after 15 days from planting and the second half after 30 days of planting. Micronutrients (Fe, $\mathrm{Mn}, \mathrm{Zn}$, and $\mathrm{Cu}$ ) were added before cultivation (foliar addition)

The yield was harvested at 190 days age. The tuber yield of each treatment was sent to the factory for sugar extracting to determine sugar percentage (determined according to Le Docte, 1927) and amino nitrogen percentage (determined according to Brown and Lilliand (1964).

The data of whole plants, roots, shoots weights and sugar yield were listed in Tables 2 and 3 for the first and second seasons, respectively. The data of whole plants, shoots, roots, sugar yield, sucrose concentration and amino N\% were computed and statistically analyzed for testing the significance of the tested factors and the possible interaction between them.

\section{RERSULTS AND DISCUSSION}

The data of obtained results (Table 2 and Fig.1) showed that potassium as an essential plant nutrient affected significantly on all plant items studied in both seasons. The data of both seasons were closed to each other as shown in Figures 1a and 1b. The second level of added $\mathrm{K}$ to soil (100 $\mathrm{mg} \mathrm{K} / \mathrm{kg}$ soil) increased significantly the whole plant weight by 40 and 53\% for the first and second seasons, respectively. The beet tubers weight also, was enhanced dramatically with the second $\mathrm{K}$ level where it increased by 28 and $39 \%$ for the first and second seasons, respectively. The results showed that the huge of shoots hunted the big part of the extent increase in the whole plant where the shoot fresh weight were magnified 75 and $90 \%$ for the first and second seasons, respectively. In spite of that huge of the fresh shoot comparing with root, the dry mater yield of shoot and root followed the contrary. Dry matter did not affected significantly by potassium addition either with shoot or root in both seasons. Sugar yield and sucrose percentage in both seasons were significantly affected by potassium fertilization rate. The sugar yield was promoted from 5.04 to 6.28 and from 4.56 to 6.16 ton/ faddan for the first and second season, respectively with the second rate of $\mathrm{K}$ added. Those extents represent $24 \%$ and $35 \%$ of the lowest addition of $\mathrm{K}$ for the first and second season, respectively.

The data of sucrose percentage illustrated negative significant effect of $\mathrm{K}$ added rates on the dry mater percentage of the root which means that more moisture of tubers leads to less concentration of sucrose. The data of third and fourth levels of added K (125 and $150 \mathrm{mg} \mathrm{K}$ $/ \mathrm{kg}$ soil) were similar to the second level and showed more or less the same effect on discussed parameters. The data of the amino nitrogen percentage demonstrated that more added $\mathrm{K}$ led to more amino nitrogen

Table 2. Effect of $\mathrm{K}$ rate on plants, shoots, roots, sugar yield, sucrose \% and amino N.\% (1st season).

\begin{tabular}{|c|c|c|c|c|c|c|c|c|}
\hline \multirow{2}{*}{$\begin{array}{c}\text { K rate } \\
\mathrm{mg} / \mathrm{kg} \text { soil }\end{array}$} & Plant & Root & Shoot & Sugar & Dry root & Dry shoot & Sucrose & Amino N. \\
\hline & \multicolumn{4}{|c|}{ 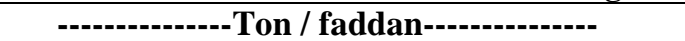 } & \multicolumn{4}{|c|}{ 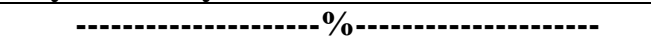 } \\
\hline K1 & $33.36 \mathrm{~b}$ & $24.86 \mathrm{~b}$ & $8.50 \mathrm{~b}$ & $5.04 \mathrm{~b}$ & 30.89 & 13.94 & 20.22 & $1.26 \mathrm{c}$ \\
\hline $\mathrm{K} 2$ & $46.63 \mathrm{a}$ & $31.79 \mathrm{a}$ & $14.85 \mathrm{ab}$ & $6.28 \mathrm{a}$ & 30.31 & 13.97 & 19.72 & $1.73 \mathrm{~b}$ \\
\hline K3 & $43.25 \mathrm{a}$ & $30.28 \mathrm{a}$ & $12.97 \mathrm{ab}$ & $5.89 a b$ & 29.76 & 13.93 & 19.52 & $1.85 \mathrm{~b}$ \\
\hline K4 & $47.34 \mathrm{a}$ & $27.86 \mathrm{a}$ & $19.48 \mathrm{a}$ & $5.03 \mathrm{~b}$ & 28.93 & 12.96 & 19.77 & $3.00 \mathrm{a}$ \\
\hline L.S.D. 5\% & 7.214 & 4.039 & 6.320 & 0.870 & N.S. & N.S. & N.S. & 0.378 \\
\hline K1 & $31.09 \mathrm{~b}$ & $22.55 \mathrm{~b}$ & $8.54 \mathrm{~b}$ & $4.56 \mathrm{c}$ & 30.94 & 13.61 & 20.00 & $1.22 \mathrm{c}$ \\
\hline $\mathrm{K} 2$ & $47.63 \mathrm{a}$ & $31.33 \mathrm{a}$ & $16.30 \mathrm{a}$ & $6.16 \mathrm{a}$ & 30.38 & 13.73 & 19.78 & $1.64 \mathrm{~b}$ \\
\hline K3 & $47.08 \mathrm{a}$ & $30.18 \mathrm{a}$ & $16.90 \mathrm{a}$ & $5.88 \mathrm{ab}$ & 29.82 & 13.86 & 19.62 & $1.80 \mathrm{~b}$ \\
\hline K4 & $45.66 \mathrm{ab}$ & $27.63 \mathrm{a}$ & $18.03 \mathrm{a}$ & $4.99 \mathrm{a}$ & 28.97 & 13.02 & 19.47 & $2.94 \mathrm{a}$ \\
\hline L.S.D. 5\% & 4.039 & 4.412 & 4.300 & $\mathbf{0 . 8 8 9}$ & N.S. & N.S. & N.S. & 0.373 \\
\hline
\end{tabular}




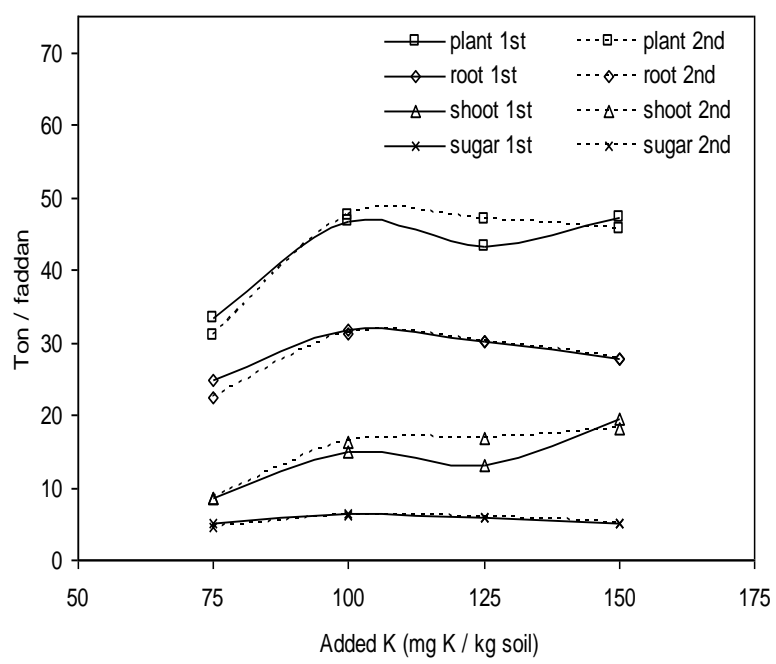

Figure 1a. Relationship between potassium fertilization rate and plant, root, shoot and sugar yields.

percentage in sugar beet tubers in both seasons especially with the highest level of $\mathrm{K}$ addition where the amino nitrogen\% was more than double of the lowest level $(238 \%)$ and was $173 \%$ of the lowest level for the first and second seasons, respectively. Results agreed with those obtained by Orlovius (1986) and Cumakov (1996).

Molybdenum as an essential plant nutrient affected significantly plant, root, shoot and sugar yield in ton/faddan, but the effect on both sucrose and amino nitrogen percentage was not significant (Table 3 and Figs $2 \mathrm{a}$ and $2 \mathrm{~b})$. The first level of Mo added to soil ( 0.1 $\mathrm{mg}$ Mo / kg soil) increased significantly the whole plant weight 14 and $16.7 \%$ for the first and second seasons,

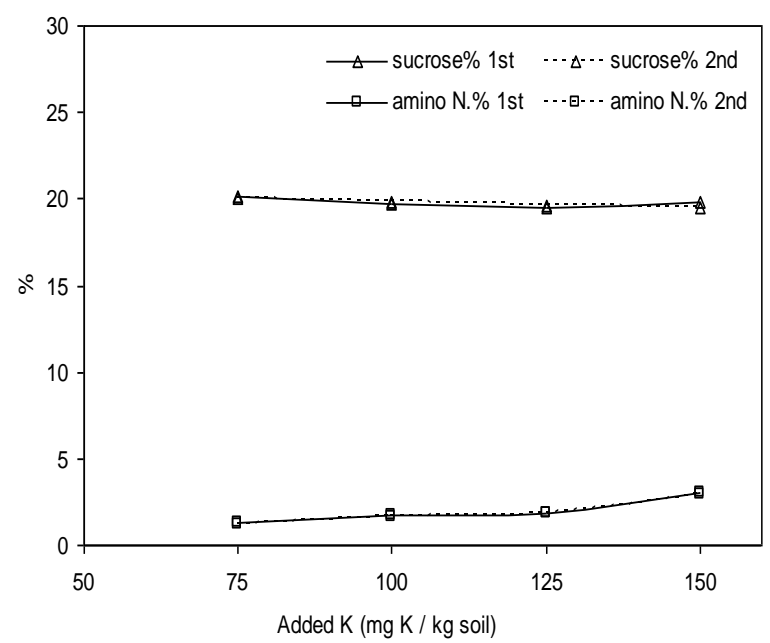

Figure 1b. Relationship between potassium fertilization rate and sucrose and amino $N$. percentage.

respectively. The second level increased the whole plant weight 20.5 and $24.3 \%$ for the first and second seasons, respectively but did not show a significant effect as the

first level. The same effect of molybdenum was noticed with the root yield, while there was no significant effect on the shoot yield. The first level cleared a significant effect where the root yield was enhanced by 27.4 and $26.7 \%$ for the first and second seasons, respectively. The dry matter percent of both root and shoot was not affected by addition of molybdenum. The data of the molybdenum effect on sugar yield in both seasons were close to each other as shown clearly in Figure 2a. Sucrose and amino nitrogen percentage did not vary significantly with the added rates of molybdenum (Fig. $2 b)$.

Table 3. Effect of Mo rate on plants, shoots, roots, sugar yield, sucrose \% and amino N.\% (1st season).

\begin{tabular}{|c|c|c|c|c|c|c|c|c|}
\hline \multirow{2}{*}{$\begin{array}{c}\text { Mo rate } \\
\mathrm{mg} / \mathrm{kg} \text { soil }\end{array}$} & Plant & Root & Shoot & Sugar & Dry root & Dry Shoot & Sucrose & Amino N. \\
\hline & \multicolumn{4}{|c|}{ 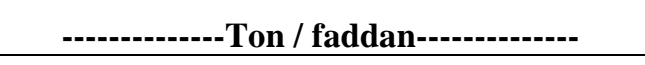 } & \multicolumn{4}{|c|}{ 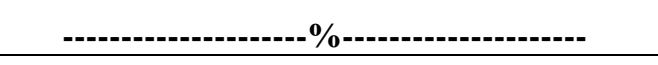 } \\
\hline \multicolumn{9}{|c|}{ First season } \\
\hline Mo 0 & $38.96 \mathrm{~b}$ & $24.65 \mathrm{~b}$ & 14.31 & $4.87 \mathrm{~b}$ & 29.91 & 13.46 & 19.74 & 1.82 \\
\hline Mo 1 & $43.27 \mathrm{a}$ & $31.39 \mathrm{a}$ & 11.88 & $5.99 \mathrm{a}$ & 30.23 & 13.68 & 19.09 & 2.19 \\
\hline Mo 2 & $45.70 \mathrm{a}$ & $30.05 \mathrm{a}$ & 15.65 & $5.81 \mathrm{a}$ & 29.77 & 13.67 & 19.32 & 1.88 \\
\hline L.S.D. 5\% & 6.248 & 3.500 & N.S. & 0.750 & N.S. & N.S. & N.S. & N.S. \\
\hline \multicolumn{9}{|c|}{ Second season } \\
\hline Mo 0 & $37.71 \mathrm{~b}$ & $24.31 \mathrm{~b}$ & 13.41 & $4.81 \mathrm{~b}$ & 29.96 & 13.48 & 19.54 & 1.74 \\
\hline Mo 1 & $44.00 \mathrm{a}$ & $30.79 \mathrm{a}$ & 13.21 & $5.86 \mathrm{a}$ & 30.29 & 13.54 & 19.19 & 2.12 \\
\hline Mo 2 & $46.88 \mathrm{a}$ & $28.67 \mathrm{a}$ & 18.22 & $5.52 \mathrm{ab}$ & 29.82 & 13.74 & 19.25 & 1.84 \\
\hline L.S.D. 5\% & 3.500 & 3.821 & N.S. & 0.770 & N.S. & N.S. & N.S. & N.S. \\
\hline
\end{tabular}




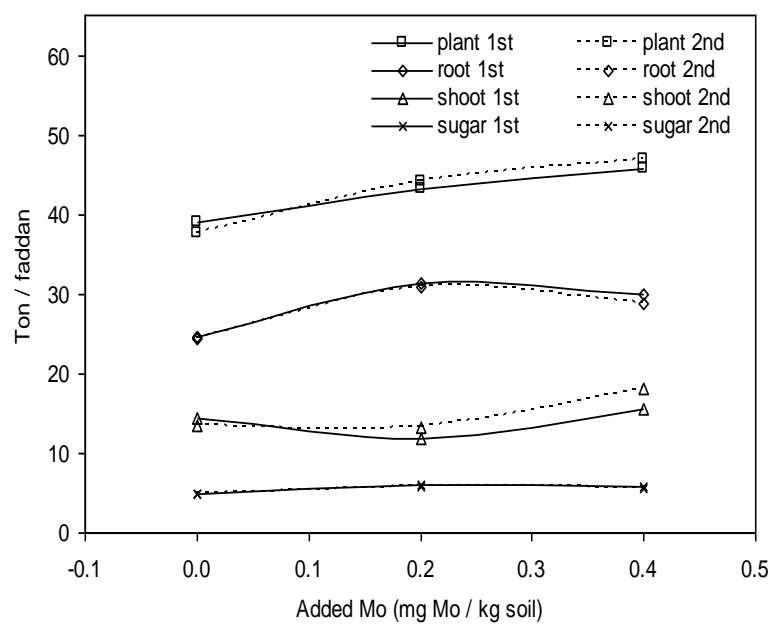

Figure 2a. Relationship between molybdenum fertilization rate and plant, root, shoot and sugar yields.

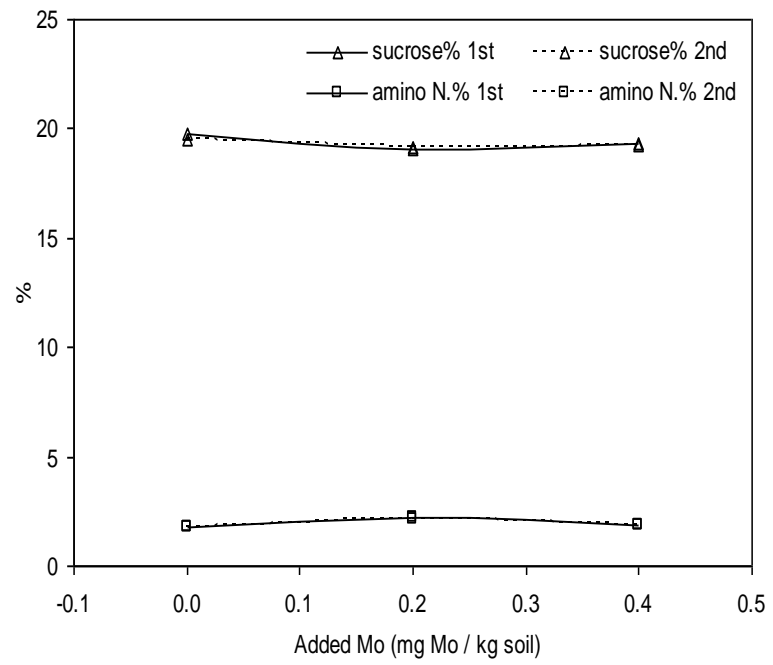

Figure 2b. Relationship between molybdenum fertilization rate and on sucrose and amino $\mathrm{N}$. percentage.

\section{REFERENCES}

Bieniaszewski, T. (1996). Effects of different NPK rates on sugar beet yield and feeding value. Agriculture, 62:63-75 [C.F. Field crop Abs., 49 (11): 8197].
Black, C.A. (1965). Methods of soil analysis. American Soc. Inc. Pub., Madison, Wisconsin, USA.

Brandenburg. E. (1931). Die Herz-und trokenfaule der Ruben als Bormangeler Schienung. Phytopathology, 3:449-517.

Brown, J.D. and 0. Lilliand. (1964). Rapid determination of K and $\mathrm{Na}$ by phlamephotometer. Proc.Amer.Soc. Hort. Sci. 48:341-346.

Chielewska, B.; T. Filipek and J. Mazur. (1991). Effect of different nitrogen and potassium fertilizer application on the content of trace elements in soil and sugar beet. IIManganese and Iron. Roczniki Na uk polniczych. 108 (2):111-123. [C.F. Field crop Abs., 44 (1): 62.].

Cumakov, A. (1996). Relations between potassium yields and quality of sugar beet. Listycukrovarnickea Reparske, 112 (I):11-17. [C.F. Field crop. Absl., 49 (6): 5751].

Draycott, A.P. and R.F. Farley. (1973). Response sugar beet to soil dressings and foliar sprays of manganese. J. Sci. of Food \& Agric. 24:675- 683.

Le-Docte, A. (1927). Commercial determination of sugar beet in the beet root using Sachr-Le- Docte process. Int. Sug. J. 29:488-492.

Mazepin, K.G. and N.M. Udovidclienko. (1980). Fertilization of sugar beet. Sakharnaya svekla , 32:582-592, 1981.

Nagarajah. S. and A, Ulrich. (1966). Iron nutrition of the sugar beet plants in relation to growth mineral balance and riboflavin formation. J. Soil Sci. 102:399-407.

Orlovius, K. (1986). Results of long-term field trials for evaluation potassium in harvest residues under different site conditions. Land wirtschftliche for schung 39:189197.

Rutskaya, S.I.; L.I. Ksenz and A.A. Sidorov. (1982). Effect of boron and zinc on nutrient uptake by sugar beet plants and crop yield in relation to rate of NPK fertilizer. Fiziol Biokhim. Kult. Rast. 1981. 13:631-636. [C.F. Micronutrient Bureau, 3 (1): 5].

Savchenko, T.L. (1980). Kinetics of nutrient absorption by sugar on derno calcareous

soil of the looser forest zone of western UK raine. Agrokhimiya. 9 (I): 67-73. (Cited after Soil Ferti., 45:84,1137-1982.

Tonkal, E.A.; V.D. Zholob; L.A. Sakunova. (1980). Effect of the proportion of potassium and nitrogen on productivity of sugar beet. Sakhrnaya svekla. (1): 27-28. [Cited after Soil Ferti., 44 (6): 582, 5130,1981]. 
140

ALEXANDRIA SCIENCE EXCHANGE JOURNAL, VOL. 28, NO.3 JULY- SEPTEMBER 2007

الملخص العربي

تأثير التسميد بالبوتاسيوم و الموليبدنم على نمو بنجر السكر فى الأراضى الجيرية

إبراهيم إسماعيل محمود

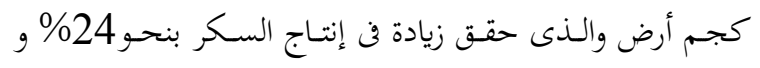

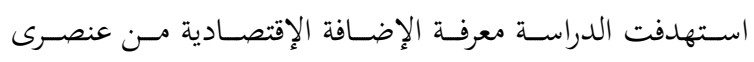

35\% موسمى الزراعة الأول والثان على التوالى.

البوتاسيوم و الموليبدنم لنبات بنجر السكر فن الأراضى الجيرية المصرية.

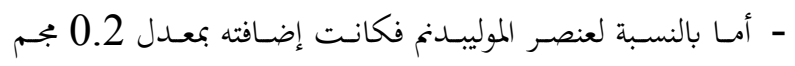

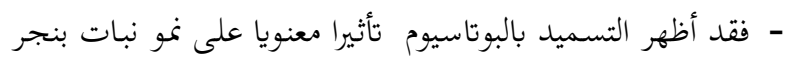

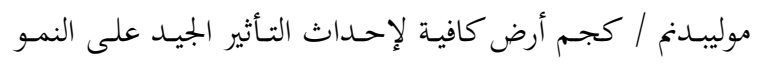

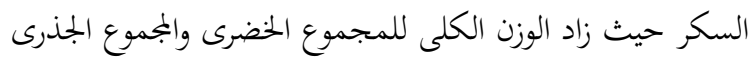

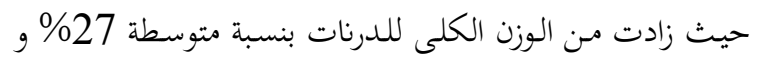

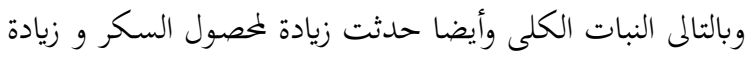

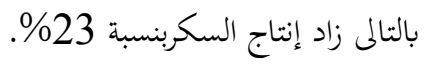

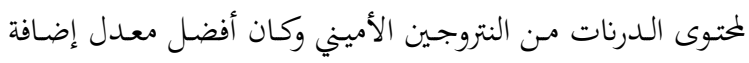
- كما أوضح التحليل الإحصائى عدم وجود تأثير مشترك بين كل لمكل

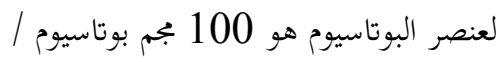
من البوتاسيوم و الموليبدن على نمو وعصول بنجر السكر الإحر 